\title{
Forensic Investigation of Homicide or Bodily Injury of a Newborn by His Mother
}

\author{
Ferariu Petronela Diana \\ "Alexandru Ioan Cuza” University of Iași, Faculty of Law, Romania \\ Legal Adviser, Company EuroAsia of Iași, Romania,dianaferariu@gmail.com
}

\begin{abstract}
In criminal law from Romania, the offense of homicide or bodily injury of the newborn committed by the mother is a special mode of homicide, with specific sanctioning rules in conditions of physical or psychological disorders. In our country, the term of homicide of a newborn has a narrower meaning than the term infanticide. Infanticide refers to murder a child and is considered in the laws of other states as a form of qualified murder. The homicide of the newborn does not refer to the suppression of the life of any child, but only to the homicide of his newborn by his mother, immediately after birth but no later than 24 hours. Forensic investigation involves expanded and complex activity, caused usually by the mother's actions from the moment of birth time to the moment of mutilation, hiding or abandoning the corpse. It is necessary to reconstruct the crime scene by identifying the place where the birth occurred, where the mother committed the offense, the area where the newborn corpse was discovered, parts of the body or traces that indicate that it was incinerated, buried, devoured by animals and so forth. Very important as well is the identification of the trail between the place of birth to the one where the corpse was abandoned or hidden, the place where the tools used to commit the crime were discovered, objects that were used at transporting the corpse or suppressing the life of the newborn as well as issues related to the legal medicine.
\end{abstract}

KEYWORDS: bodily injury, crime scene, forensic, homicide, infanticide, investigation, murder of a newborn, offenses committed against a family member, psychical disturbance of the mother

\section{Introduction}

Current Romanian Penal Law provides a distinct title of the infractions against the person. Through these incriminations life is protected, physical integrity and the person's health from the time of the birth to the moment his death occurs in a natural way. The offence of murdering a newborn by the mother, is a variety of murder offence committed in specific circumstances and that justifies distinct incrimination with a penal sanction attenuation. The act of homicide committed by the mother has a narrower meaning than the term of the infanticide. The latter refers to the murder of a child after 24 hours of birth and is considered in the laws of other states as a form of qualified murder (Iftenie and Boroi 2002, 99). In Romanian Law, the attenuation involves the existence of certain psychological-physiological states caused by birth, that are not equivalent with a state of unconsciousness, but they are capable of explaining, to a certain extent, the action of homicide a newborn. The legislator sanctions more easily, in comparison to the delict of murder, this type of act committed by the newborn's mother, recognizing the possibility of occurrence of such states of disorder. In order to protect the mother who has murdered her own newborn in physical or mental disorder conditions, with less discernment, from a more severe punishment, it was considered necessary to introduce a distinct article that would delimit the homicide of the newborn by the offense of murder (Vasile 2013, 107).

The victim of the offence must be a newborn having no importance if the infant is a child from marriage or outside marriage. The condition of the newborn involves the birth process. Such a process starts with specific uterine contractions, accompanied by pain and then gradual detachment of the child from the mother's body, completed with his expulsion. The newborn is considered to be the child who still carries the signs of the recent birth, but no more than 24 hours afterwards (Cristiean and Buzatu 2008, 310). In order to accomplish the offense, it is essential that the newborn be alive at the time when the murder deed is committed. It is important that the birth process is completed, that the fetus expelled and to begin a life independent of the mother's life. If the act was committed before the end of the birth process, the offense of bodily injury to the fetus will be retained. In the judicial practice in our country, it was decided that he does not commit this homicide, not fulfilling the condition that the deed should be committed immediately after birth but not more than 24 hours thereafter, the mother who murder newborn two weeks after her birth, after 
discharge from the hospital regardless of the mental state in which she was at the time of committing the criminal act. The 24-hour delimitation period leads to significant consequences in terms of legal classification of the offence. A homicide or injury of the newborn is the killing or injury caused by the mother only up to the 24-hour limit (Iftenie and Boroi 2002, 101). The same offense is also sanctioned when the homicide took place during this period, but the newborn death occurred subsequently. If the 24-hour period passes, even if the state of postnatal psychiatric disorder persists, the act will no longer constitute the offense of homicide or injury of the newborn committed by the mother but the offense of murder. Determination the state of psychological disorder is based on scientific and medical data, following a forensic expertise. The mother's attitude of pursuing or accepting the result of her actions must be spontaneous, determined only by the state of psychological disorder, and must manifest itself simultaneously, within the time when that condition exists, premeditation being impossible. If the mother acted intentionally, she would be criminally responsible for committing the offense of homicide or bodily injury a newborn (Iftenie and Boroi 2002, 103).

The forensic investigation of the offense of homicide of a newborn is a very important issue as it requires a lot of attention, focus, objectivity and involvement from the entire team taking part in the investigation at the crime scene. In the case of the homicide offense of a newborn, the crime scene includes a fairly large and varied area, determined by the mom's actions from the moment of birth to the moment of mutilation, hiding or abandoning the corps. The victim's forensic characteristic in the case of homicide offense of a newborn includes the following defining signs and the research must establish the newborn condition, the lifetime of intrauterine and extrauterine life and the degree of maturity and viability of the fetus. Obstetric science considers that the length of a mature newborn is 47-62 centimeters (more frequently 50-52 centimeters) and that of premature less than 45 centimeters (Huidu 2010, 204). It is considered that the weight of a mature newborn is around the limits of 2500-3500 grams. The weight of the fetus in the 7th month of intrauterine life is between 1000-1400 grams, in the eighth month from 1500 to 2400 grams, and in the ninth month around 2500-3500 grams (Huidu 2010,204). Viability is to be understood as the ability of the baby to survive outside the maternal body. From a clinical point of view, the fetus born in the second half of the 6th month of intrauterine life is considered viable, with a length of not less than 35 centimeters and a weight of at least 900-1000 grams, which may exist outside the body woman in special conditions (Huidu 2010, 206). The absence of a newborn child's condition leads to the different legal classification of the offence and the application of other investigative techniques than those characteristic of the offense of the homicide the newborn.

The criminal investigation team at the crime scene must reconstitute the scene of the offense by identifying the place where the child was born, where the offense was committed, the area in which the newborn's cadaver was discovered, parts of the body, or traces in which resulted it was incinerated, buried, devoured by animals and so forth (Lăpăduşi and Iancu 2004, 164). Also, they must establish the mother's trail from the place of birth to the place where the newborn baby's corpse was abandoned, as well as discovering instruments, objects, containers and so forth used in the birth, packaging, transporting of the body or suppressing the life of the newborn (Vasile 2013, 110).

\section{The criminal forensic investigation at the place of birth}

A first aspect that research should make clear is the place where the child was born, was injured or homicide occurred. Following the determination of the place of birth, the criminal investigator can determine if the mother gave birth in conditions assisted by a nurse, a child whom he injured killed or abandoned immediately after birth. Although the place is not relevant to the legal classification of the offence of the homicide, its is particularly important for establishing evidence of the criminal offense of homicide of the newborn. In order to achieve the objectives inherent in the investigation of the homicide of the newborn, the limits of the space where the child was murdered (room, apartment, dwelling, courtyard, forest, field, and so forth) must be established (Bulgaru-Iliescu, Costea, Enache, Gheorghiu, Astărăstoae 2013, 604). Considering the legal provisions and the practice of the judiciary, it is argued 
that the place where the crime was committed differs from case to case, in relation to the nature of the deed, with the multitude of methods and resources used for that purpose, with the specifics of the illicit activity lead by the perpetrators. The notion of a crime scene in the case of a crime of homicide of a newborn child comprises a fairly diversified area, generated mainly by the actions of the perpetrator from the time of the birth and to the moment of hiding or abandonment of the corpse. For example, in the case of unassisted births by the medical nurse, due to its physiological state, the pregnant woman can not move for a longer distance place. Thus, births of this kind occur in places close to the house where the mother usually lives. Therefore, the place of unassisted birth often becomes a place of committing injury or of homicide the newborn child by his mother (Tudor 2010, 183). Among the specific traces of recent births the following can be mentioned: the presence of afterbirth on the mother's body, of blood, amniotic fluid, rupture of the perineum, the presence on the newborn body of blood traces, meconium and the vernix caseosa substance (a white cheese-like protective material that covers the skin of a fetus), signs of umbilical cord, and so forth. In the place where the birth took place bloody clothes can be found, gauze, obstetric instruments, containers used for collecting birth-related liquids, and so forth (Dermengiu, Alexandrescu 2014, 134).

At the crime scene, on the corpse and on objects that have entered the perpetrator's sphere of interest, the prints of her hands can be traced. Fingerprints can also be found on objects, instruments used by the perpetrator to commit the crime, scissors, obstetric instruments, ropes, and so forth. These traces can also be found on the objects in which the newborn was abandoned: boxes, plastic bags, bags, and so forth. In addition to papillary prints, traces of foot or footwear can also be found at the crime scene. By analyzing them, the expert can solve the following problems: determining the approximate age, waist and weight of the perpetrator, as well as her anatomo-pathological particularities. Knowing the typical information about the place where the crime of homicide a newborn happened, has a special significance for carrying out procedural, forensic and investigative-operative activities in order to investigate and fully discover the deed (Lăpăduși and Iancu 2004, 169). The objectives of the crime scene investigation are to discover, research, preserve and collect the present traces, determine the circumstances in which the offense was committed and the data to help identify the perpetrator (if her identity is unknown) (Vasile 2013, 113). The investigation at the crime scene includes a static stage and a dynamic stage. The static phase implies the research of the traces that are found there, the state of the place where the newborn body was found, the biological human traces such as birth, menstruation, breastfeeding, bleeding of various causes or other fragments of tissues or organs. It is worth noting the characteristics of wounds when they exist, the type of lesions, location, number, color, shape, dimensions, orientation, appearance of the edges and angles and their contents, as well as objects that are not to be cleaned or packed in cotton wool, so the traces are not erased (Budăi and Gavriș 2006, 44). The examination corresponds to a close collaboration between forensic doctor and criminologist. Photos of orientation, photographing of main objects and sketches should be made by the criminologists from the team. The sketches render the entire recording of the relationship between the child's body and the surrounding objects. To describe the location the cardinal points are envisaged, nearby buildings, if they are in an open space, room objects and biological traces. It must be mentioned that the place where the newborn's body is discovered does not always coincide with the place where the body injury occurred. Most of the time, the aggressor mother attempts to hide the traces of her deed, abandoning the newborn's body in a variety of places, such as garbage, canals, stairwell, trains, less populated places, and so forth.

In the dynamic stage, the objects in the investigated perimeter are examined, after which they are moved. There is an external body examination after the complete undressing. Violent injuries, biological and non-biological traces, external signs of different illnesses, particular signs and resulting from therapeutic procedures are noted (Budăi and Gavriș 2006, 46). The photographic recording of the traces and the body of the child takes place, as far as possible in color, to highlight traumatic injuries. If the child's body was dismembered by the mother in order to conceal identity or make the identification impossible, each part of the body, the place and the position in which it was found are photographed, and after reconstitution, the body is photographed in its entirety. The 
probable date of death is determined, as far as possible, and the significance of the lesions of violence.

The collection, packaging and sending of evidence shall be carried out for laboratory examinations. If it is suspected that it was a mechanical asphyxiation by compressing the throat with a chain, the material evidence is raised to the extent that it is identified. If it is supposed to be a drowning, water evidence is collected. If the victim's body was buried, exhumation is required for the examination of the body by autopsy. The forensic doctor that performed the autopsy will draw up an expert report, which will contain his conclusions about the way of death, the medical cause of death, traumatic wounds premortem, the mechanism of their production, the legality of criminal offences between traumatic injuries and death, results of laboratory investigations performed on the biological matter taken from the corpse and suspected discovered substances, the biological traces found on the body of the newborn, the probable date of death, and any other elements that may contribute to the elucidation the case.

\section{Forensic examination of the mother}

The status of the mother, which the law requires, must be established by the criminal investigation authority each time. The jurisprudence demonstrates, within the research, that the most frequent homicide offense or injuring of newborn is committed under the conditions of an unassisted birth by a medical nurse, which excludes the certificate of the birth, capable of contributing to the identification of the perpetrator. It is of great importance to clarify this aspect of the obstetrical examination of the mother. In some situations, women suspected of committing the crime of the newborn are detected at relatively short intervals, and it is possible to find the signs of the recent birth. Other times, the examination is done at longer intervals, favoring the finding of multipara signs (women who have had more than one pregnancy). It has to be demonstrated whether the suspect woman gave birth or not, for example she fulfills the mother personal circumstances, from a legal point of view and whether she was in the childbed period, from a medical point of view (Dermengiu and Alexandrescu 2014, 136).

The forensic expertise of the woman suspected of committing a crime of killing a newborn involves three stages. Forensic examination is made in order to establish the retrospective diagnosis of pregnancy and childbirth, how the child was born and the following period. During the clinical examination of the mother, a general clinical examination, a genital examination, and an examination of products and objects found at the place of birth will be performed. General clinical examination will be carried highlighting the characteristic changes in pregnancy (hyperpigmentation, breasts raised in volume, presence of colostrum secretion in the early days, dairy secretion after 2-4 days, recent stretch marks with a rosy color, old stretch marks are white pearl shades). In the genital examination, the uterus involution will be highlighted, with an average rate of 1.5-2 centimeters a day. There may be cases of super involution, at a rate of over 2 centimeters a day, or underinvolution, at a slow rate of less than 1.5 centimeters per day. In the first hours, the uterus is reduced to the size of a pregnancy corresponding to the fourth month, after 1216 days the pelvic organ is recovered. Within 5-6 weeks, the uterus returns to the usual shape and volume and the cervical canal is wide open for the first 3-5 days (Beliș 1995, 399). The inferior segment of the uterus returns to isthmus to 5-6 days with the permeable holes, the external opening is wide open, edematous, with small fissures after the first 2-3 days. The internal opening allows the penetration of a finger, and the external one in the transverse slot with some lateral edges permits the penetration of 1-2 fingers. The cervix with the internal opening closed and the external opening extensible allows the penetration of a finger to 10-12 days. The cervical canal has normal size at 1214 days, and the external opening is completely restored after 14-16 days (Beliș 1995, 399). The vaginal canal is wide in the case of women with multiple births, the vaginal walls are extensible, the folds are wiped, and the mucus is purple. The intact hymen is an absolute proof of the lack of birth on vaginal way. The perineum may show ruptures or scars. The scarring of perineal ruptures is carried out and at the end of the first week, the granulation tissue appears. Colostrum occurs after birth as a mammary secretion and is replaced by dairy secretion after 5-6 days. The breast milk occurs 5-6 days after birth and lasts after the childbed period too. If the woman will not breastfeed, mother's secretion will gradually decrease, going to disappear after 8-10 weeks (Beliș V., 1995. 
400). In laboratory examinations, biological pregnancy tests remain positive up to 10 days after birth, and the smear of mammary secretion reveals muriform corpuscles.

As for the examination of the products and objects found at the place of birth, the placenta will be revealed, umbilical cord, amniotic fluid, meconium, blood stains, and so forth. Maternal death after giving birth exclude the criminal action for the act of homicide of the newborn. For this reason, it is necessary to evaluate pregnancy or birth signs of the body. These signs involve macroscopic and microscopic visceral changes, placental and ovarian remnants or the presence of dead fetus in the uterine cavity. In this situation, the fetus may be mummified, reduced in volume in the absence of amniotic fluid and yellowish-brown color (Iftenie and Dermengiu 2014, 495). In the $5^{\text {th }}-6^{\text {th }}$ months, the fetus may pass a maceration process, the tissues are soaked with serosity, the skin is brown, covered with fistulae containing a reddish serotype. It should be noted that in the 7 th month the umbilical cord reaches 40 centimeters, and at birth 47-52 centimeters. The premature fetus has no hair but lanugo (lanugo is hair with a puffy look). The newborn also has secondary hair, 2-3 centimeters long (Dermengiu and Alexandrescu 2014, 342).

\section{Psychiatric forensic examination of the mother}

The psychiatric forensic examination will be carried out immediately after birth in order to determine the psychiatric disorders that could have caused the offense of homicide of the newborn or, if it is impossible, at an undetermined interval after birth, for reconstitution, on the basis of the case files and the circumstances in which the child was born, any psychiatric disorders that caused the act to be committed. The examination must be complete and detailed and is considering basic psychic functions. It is of an overwhelming importance because it captures the psychological picture of the perpetrator and the psychic state that he had at the time of committing a crime. The psychiatric forensic examination is mandatory in the case of homicide or injuring the newborn child or the fetus by the mother. The psychiatric examination follows the etiology of the woman's mental disorders during childbirth. They can be systematized in pathological conditions related to pregnancy and its development, psychiatric disorders in pregnancy toxicology, confusing states through cerebral anemia due to hemorrhage, mental disorders accompanying the obstetrical act, pre-existing latent psychiatric conditions and triggered or aggravated by pregnancy, birth or psychosis (Dragomirescu, Hanganu and Prelipceanu 1990, 80).

Starting from the premise that the psychiatric expertise has as objective the establishment of a person's mental state, it can be noticed that in the case of investigating and judging the crime of homicide or bodily injury of the newborn, the main purpose of the expertise is to prove the state of psychological disorder in which the mother was at the time of injuring or homicide the newborn child. In the investigation of the offense, the psychiatric expertise should clarify whether there was any mental illness, the causation between the psychological disorder and the committed criminal activity and the fact of whether his mother was found, at the time of birth, in a state of disorder caused by it (Dragomirescu, Hanganu and Prelipceanu 1990, 81). From a medical point of view, it is accepted that any birth causes profound changes in the body of the woman. In the notion of psychological disorder, elements and facts have to be taken into account which have as a consequence of exacerbation the special mental states, relating to in some cases to the process of birth. For legal classification of the offence it is necessary to establish with certainty the existence of the mother's disorder at the time of committing the deed. The expertise should be complex, to contain psychological tests and decide on the structure of the personality of the examined woman (Ionescu 1997, 205).

In order to obtain conclusions within the psychiatric expertise performed on the investigated mother, the competent judiciary bodies must collect data including the social and family conditions of the subject under the examination, as well as the medical history of the subject. In jurisprudence, on the occasion of performing psychiatric expertise, in many situations there have been identified conditions related to limited intellect, abolished maternal instinct, oligophrenia of varying degrees of severity or impulsive psychopathy, these being envisaged in the determination of the state of disorder during childbirth. The conclusions of the forensic expertise report, first, it must specify the basic diagnosis and diagnosis of the suspect or defendant's current state, with the exclusion of 
simulation (Vlădoiu 2007, 236). The report should also include the essential features of the personality of the person being examined, reflected in the diagnosis mentioned and the deviant behavior, as well as the disorder that characterizes the current state. It is worth mentioning the evolutionary stage of these disorders, whether or not they are episodic, whether they were triggered at the time of committing the deed and whether they pose a risk of aggravation or become chronic. Last but not least, the report should mention whether, through the pathological traits and personality and behavioral disorders, favored by exogenous or endogenous factors, the perpetrator presents a social or potentially criminal danger, which may also be the basis of the argumentation of the proposed preventive and recovery measures. The conclusions must also mention the causation between the features, personalities or main manifestations of the mental illness and the constituent elements of the offense, and whether these psychopathological disturbances or manifestations alter the discernment (Vlădoiu 2007, 238). The most important aspect in the psychiatric forensic examination report should clarify whether at the moment of homicide or injuring the newborn, the mother was in a state of psychological disorder or not, because otherwise she will not be detained liability for the offense of homicide or injuring the newborn, but for the crime of murder or injury. Women who have homicide newborns, often suffer from anxiety and depression. Anxiety usually occurs as a reaction to stress or other complex pathological disorders. It can often cause diminishing the individual's intellectual performance, leading to behavioral disturbances and even criminal behavior (Cartwright 2010, 167). In order to differentiate the offense of homicide or bodily injury of the newborn from the murder offense, the investigation must make clear whether or not the mother who has killed the newborn child immediately after birth, but not later than 24 hours, is or not in a state of birth-related disorder.

\section{The forensic expertise of the newborn}

Concerning the clarification of the cause of injury or death, it is of particular importance if we consider that it is one of the indispensable conditions for the crime of homicide of the newborn. For the offense of homicide of the newborn, it must be clear from the evidence's element that the injury or death is violent and is because of the action/inaction made by the mother. The aptitude of the act of violence to suppress the life of the newborn child is deduced from its materiality, including: the instrument used and considered killing, the large number of strokes applied, their intensity and their orientation to the vital regions of the victim's body, and so forth. In the case of an offense of homicide or bodily injury of the newborn, given the child's fragility and total dependence on the person who has given birth to him, the actions used against the victim are usually of lower intensity (Dungan, Medeanu and Pașca 2010, 148). At the same time, the research needs to clarify whether it is an accidental death or homicide of a newborn. In this regard, the forensic doctor must conduct a thorough examination to determine whether or not the signs of a violent death are present, and the causes of the triggering, determining whether death is accidental or provoked.

\section{Diagnosis of children born at term}

The diagnosis of children born at term is based on some morphological elements. In terms of weight, at birth the girls must have approximate 2800-3200 grams and the boys 3000-3500 grams. Girls have to measure 48-51 centimeters and boys 50-54 centimeters. If they are less than 45 centimeters, they are considered premature. The cranial perimeter should measure about 35 centimeters and the thoracic perimeter approximate 31 centimeters (Moraru 1967, 461). The skin should be pinksh, elastic, lanugo (hair very thin, soft, usually unpigmented) on the forehead on the forehead and and vernix caseosa substance on the body. The hair has 1-3 centimeters, and the fingernails exceed the finger pulp. External genital organs are normally conformed, with testicles in scrotum, the closed vulvar slit and the large labia covering the small ones. From the third month, the embryo becomes a human fetus, and in the last three months of pregnancy the external appearance undergoes major changes, the disproportion between the head and the other segments diminishing centimeters (Ioan 1967, 466). Age can be calculated by the length of the fetus, after the identification of the ossification nuclei or after the appearance of the dental 
alveoli. In the sixth month, the alveoli of the incisors begin to form, and in the seventh and eighth month the molars are formed.

\section{The case of homicide or bodily injury of newborn committed by the mother}

In the case of assisted birth by the medical nurse, in terms of violence on the newborn, round or oval shaped bumps and semilunar excisions can occur on the scalp, at the facial and cervical. In contrast, injuries from criminal asphyxia by strangulation are unevenly located, having an irregular shape. Other traumas may consist of rupture of the buccal walls, facial lesion and the production of semilunar echinoses mimicking nails, clogging of the eyeball through digital pressure, cervical damage by hyperextension, cranial fracture produced by pressing the two parietals and last but not least a jaw fracture in the medial portion (Tudor 2010, 182).

In the case of homicide committed by the mother, a forensic autopsy of the fetus or newborn is ordered. A forensic autopsy of a fetus is ordered to establish intrauterine age, extrauterine survival ability, the type and cause of death, and the establishment of parentage when required. The forensic autopsy of a newborn is ordered to determine whether a living child was born and to determine the viability, duration of extrauterine survival, the way and cause of death, the date of death, and whether medical care were given after birth. The objectives of this operation are general and specific. The general considerations are whether the newborn is of the presumed mother, whether it was born alive, whether the death occurred immediately after birth, the duration of the extrauterine life, the quality of care given to the newborn, the precise setting of the date and the type of death, as well as establishing the traumatic lesions of the production mechanism and their causation with death. The specific objectives are to demonstrate the existence of extrauterine life and the violent nature of death (Scripcaru, Astărăstoae and Scripcaru 2005, 112).

Externally, the fetus or newborn's body will be examined, as well as the textile material used for its wrapping, the packaging it will be described and any of the evidences. These are collected as biological proof for forensic and serological-genetic analysis. Identification and customization take place, mentioning the gender, height, weight, gestation age, extrauterine life, and other anatomical features that the forensic doctor appreciates. Then the signs of the real death are noted, such as lividity and stiffness postmortem, and signs of putrefaction. The body is weighted and measured. Weight is appreciated taking into account the dehydration processes through which the fetus has passed. The unviable fetus, which after the first seven months did not reach 1000 grams, is considered abortion (Dermengiu and Alexandrescu 2014, 331). The head size is mentioned, cranial diameter and circumference, circumference of the chest and abdomen, bihumeral, bitrohanterian, and bicistar diameters, and the distance between the xifoid appendix and the umbilical ring and the distance from the umbilical to the pubis. The umbilical cord insertion level on the abdominal median line is lower for the low age fetus. The external exam records the appearance of the skin, with hairs or hair with a look of puff on the back and on shoulders at fetuses and premature babies. In the case of prematures, the nails of the upper limbs do not cover the finger pulp. The subcutaneous tissue is poorly represented, the head is small, the face is triangular, the abdomen is voluminous, and the chest is enlarged at the base. Meconium is present at the newborn. Also, in the external examination, the existence of possible deformations should be mentioned, the length of the hair, the condition of the oral cavity, the consistency of the nasal cartilage and pavilions of the ears, the presence or absence of the testicles in the scrotum or if the big labia covers the small ones. The umbilical cord should be described in detail, with the indication of its length if it is attached to the placenta and what is the general appearance. The newborn recently has a consistent pearly white cordon. In case of death by intrauterine asphyxia, the umbilical cord is greenish and impregnated with meconium. Its end may be cut or broken. The umbilical plaque is scarred after about 2 weeks. On the placenta, the shape, face aspect, diameter, weight, color, consistency and structure should be described. It should be specified if it is completely removed or attached via the cord to the fetus and the mature newborn should have 500-550 grams (Moraru 1967, 464).

The external examination is performed on anatomical regions. In the facial the eyeballs are envisaged. On a premature newborn child, the pupillary membrane is rich in capillary and it 
disappears in the eighth month of pregnancy. In the cases of death under 24 hours, the cornea is opalescent. In the auricular region, secretions may appear in the external auditory conduit. As for the anal region, the permeability is tested with a probe. On boys, the testicles penetrate into the inguinal canal in the 7 th month, being present in scrotum in term. The bone system targets skull skeletal mobility in dehydration and aerated fetus the dehiscence of sutures in obstetrical trauma, and possible malformations such as hydrocephalus or meningocele.

The internal exam begins with an anterior medial incision, cranio-caudal, at the level of the lower lip, lowering the neck, chest and abdomen. Determining the medical cause of injury or death of the fetus or the newborn. According to the way of death, intrauterine deaths are divided into violent deaths and nonviolent deaths, the violent ones can be accidental or homicide. They may be due to mechanical factors such as traumatic injuries to the pregnant or fetus, physical factors such as irradiation, burns with hot liquids or with flame or chemical factors, such as poisoning. In the seventh month, strong abdominal trauma can affect birth. A differential diagnosis of the lesions due to obstetric maneuvers must be made in relation to those resulting from acts of violence. If there has been a non-violent death, there may be general maternal causes such as pneumonia, viral infection, malaria, syphilis, cardiopathy, local maternal causes, fetal causes such as placental stroke or twisted umbilical cord and so forth. During pregnancy, it may be a pathological death or a death in consequence of the traumas suffered (Budăi and Gavriș 2006, 78). The Following maternal and fetal causes, death can be due to infections, uterine and vaginal malformations, fetal edema, macrosomes, placental detachment, risk of massive amniotic fluid aspiration, or umbilical cord pathology. At birth, asphyxia may occur during normal labor as a result of uterine contractions with a decrease in gas exchange. Postpartum death of the newborn may be due to a pathological cause or to the violence suffered. Aggression exerted on it involves mechanical asphyxia by obstruction of breathing holes by hand or with a textile material, drowning in lakes or rivers, burial in sand or ground, mechanical asphyxia toraco-abdominal compression, asphyxia by inserting a child in plastic bags or exposure to high temperatures or electric shock. The medical examination of the newborn body must meet the general and specific objectives. It must be settled down whether the newborn belongs to the presumtive mother, if it was born alive, if the death occurred immediately after birth, the duration of the extrauterine life, the quality of care, the date and cause of death, the traumatic lesions, the mechanism and their causation with death (Beliș 1995, 412). Essential in homicide offense or bodily injury of newborn by his mother, is the demonstration of extrauterine life. The most important criterion is the achievement of lung breathing. It does not matter if the newborn has completely detached or not from the mother's body, if the umbilical cord has been removed or the placenta has been expelled.

\section{Methods of homicide or bodily injury of newborn}

In forensic practice, the notions of homicide or injuring the newborn, active and passive, are used. Homicide or injuring active newborn indicate, according to statistics, the most commonly used method is asphyxia in various ways, used in $48.5 \%$ of cases. In most cases, there are no traces of violence, only the general signs of asphyxia, which require certification through a histopathological. Asphyxia by introducing foreign bodies into the mouth and pharyngeal appears in $4 \%$ of cases. Foreign bodies can be clothes, cotton, paper, toys, identified in their entirety or in the form of fragments in the oropharynx (Cartwright 2010, 177). In many cases, there are also traces of violence in the form of bruising/ecchymosis, excoriations or erosion on the mucous membranes. Suffocation occurs less frequently, by burial in the ground. The hypoxic process is prolonged, in the respiratory apparatus grains of sand being identified, soil, or other foreign bodies. Strangulation is present in 7\% of cases, being committed with soft objects such as scarf, handkerchief or harsh and semi-rigid chains, belt, or wire, and so forth. Toraco-abdominal compression occurs in 3\% of cases. The drowning of the newborn occurs in $13.5 \%$ of cases. Repeated injuries with hard objects in the cephalic extremity was found in $12 \%$ of cases. The hitting is usually multipolar with multiple hematomas and fractures and it is accompanied by meningeal haemorrhage. The homicide of the newborn by/through physical factors, burning or scarring of the newborn occurs in very rare cases, and the one committed by poisoning does not appear in the 
statistics. Passive homicide or injuring the newborn is manifested by abandoning of the newborn under cold conditions or the abandonment of the newborn in isolated places after birth.

\section{Conclusions}

Forensic medical and medical-social studies in cases of homicide or bodily injury of a newborn by his mother, as well as experimental research, allow conclusions to be drawn that represent the essence of all the research on the offense of homicide of the newborn over the years. The place where the woman lives or the environment in which she spends her daily life has a decisive influence on the number of facts that happen in our country. Inhuman living conditions refer both to the inherent shortcomings of any critical situation and to the affective state of the mother. Similarly, the problem of those who do not have a job is questioned, this aspect generating an insufficient moral balance, being a factor of negative influence. Following the statistical surveys conducted, was concluded that two thirds of the perpetrators are very young women, many of them even minors and without occupation. The lack of training, both in the family and in society, on sexual life leads, to homicide deeds. In examining the causes that have led to the homicide or bodily injury of a newborn, forensic expertise has a particularly important role. This important role is conferred by the existence of a complete dossier showing all the phases and means used as accurately and objectively as possible. However, the homicide or bodily injury of a newborn by his mother is difficult to investigate, due to impediments to determining the cause of death, of the probation regarding the viability of the newborn or to establishment the death of the newborn immediately after birth but not later than 24 hours.

\section{References}

Beliș, Vladimir. 1995. Tratat de medicină legală-volumul al II-lea (Treatise in Legal Medicine-Volume II). Bucharest: Editura Medicală Publisher.

Budăi, Remus, Gavriş Radu. 2006. Ghidul anchetatorului de omoruri (Guide to the Murder Investigator). Pitești: Argessis Print Publisher.

Bulgaru-Iliescu, Diana. Costea, Gabriela. Enache, Alexandra. Oprea, Liviu. Gheorghiu, Valentin. Astărăstoae, Vasile. 2013. Expertiza Medico-legală psihiatrică. Abordare interdisciplinară (Forensic Psychiatric Expertise. Interdisciplinary Approach). Iasi: Timpul Publisher.

Cartwright, Duncan. 2010. Minți criminale-Psihanaliza violenței și crime (Psychoanalysis, Violence and Rage-Type Murder. Murdering Minds). Bucharest: Trei Publisher.

Cristiean, Victoria. Buzatu, Nicoleta-Elena. 2008. "Pruncuciderea. Aspecte de ordin juridic, criminalistic şi medico-legal". In România - Uniunea Europeană. De la aderare la integrare, vol. I. ("Infanticide. Aspects of Legal, Forensic Science and Forensic Medicine". In Romania - European Union. From accession to integration). Bucharest: Pro Universitaria Publisher.

Dermengiu, Dan. Alexandrescu, Gheorghe. 2014. Medicina legală prosecturală (Forensic Medicine). Bucharest: Viața medicală românească Publisher.

Dragomirescu, Virgil. Hanganu, Octavian. Prelipceanu, Dan. 1990. Expertiza medico-legală psihiatrică (Forensic Psychiatric Expertise). Bucharest: Medical Publisher.

Dungan, Petre. Medeanu, Tiberiu. Pașca, Viorel. 2010. Manual de drept penal. Partea specială. Infracțiuni contra persoanei vol. I (Criminal Law Handbook. The Special Part. Crimes Against the Person Volume I). Bucharest: Universul Juridic Publisher.

Huidu, Alexandra. 2010. Reproducerea umană medical asistată (Medical Assisted Human Reproduction). Iasi: Lumen Publisher.

Iftenie, Valentin. Boroi, Alexandru. 2002. Infracţiunile de lovire şi vătămare a integrităţii corporale sau a sănătăţii. Cadrul juridic. Aspecte medico-legale (Offenses of Bodily Injury of Integrity or Health. Legal Framework). Bucharest: Editura Juridică Publisher.

Iftenie, Valentin. Dermengiu, Dan. 2014. Medicină legală. Curs universitar, ediția a II-a (Forensic Medicine. University Course, 2nd Edition). București: C.H. Beck Publisher.

Ioan, Moraru. 1967. Medicină legală (Forensic Medicine). Bucharest: Medicală Publisher.

Ionescu, George. 1997. Tulburările personalității (Personality Disorders). Bucharest: Asklepios Publisher.

Lăpăduși, Vasile and Iancu Ștefan. 2004. Investigarea criminalistică a locului faptei (Forensic Investigation of the Crime Scene). Bucharest: Luceafărul Publisher.

Scripcaru, Gheorghe. Astărăstoae, Vasile. Scripcaru, Călin. 2005. Medicina legală pentru juriști (Legal Medicine for Legal Adviser) Iași: Polirom Publisher.

Tudor, Georgiana. 2010. Răspunderea juridică pentru eroarea medicală (Legal Liability for Medical Error). Bucharest: Hamangiu Publisher. 
Vasile, Viorel. 2013. Investigarea şi cercetarea infracţiunilor îndreptate împotriva vieţii, integrităţii corporale şi sănătății persoanei (Investigation of the Crimes Against the Life, Body Integrity and the Health of the Person). Bucharest: Ministry of Internal Affairs Publisher.

Vlădoiu, Nasty Marian. 2007. Protecţia constitutională a vieţii, integrităţii fizice şi a integrităţii psihice (Constitutional Protection of Life, Physical and Mental Integrity). Bucharest: Hamangiu Publisher. 